\title{
Influence of the change in the shape of the corneal epithelium removal in postoperative PRK visual acuity.
}

\author{
Influência do formato da desepitelização corneana sobre \\ a acuidade visual no pós-operatório da ceratectomia \\ fotorrefrativa (PRK)
}

Vanessa Yumi Sugahara Harada ${ }^{1}$, Flávia Lúcia Beraldi Rangel ${ }^{1}$, Sara Silva da Silva Lopes ${ }^{1}$, Daniella Villas Boas Fairbanks Barbosa', Fabio Naoki Hino², Luís Gustavo de Imparato Rodrigues Ribeiro', Fernando Antonio Galhardo Tarcha', Edmundo José Velasco Martinelli ${ }^{1}$, José Ricardo de Carvalho Lima Rehder ${ }^{3}$.

\begin{abstract}
Objective: To determine if the change in the shape of the corneal epithelial removal in photorefractive keratectomy (PRK), from circular to oval shape, modifies the recovery of the postoperative visual acuity (VA). Methods: Forty-three (43) patients subjected to bilateral simultaneous PRK were prospectively evaluated. Randomly for each patient, one eye underwent epithelial removal in circular shape and the other in oval shape. On the sixth day of postoperative period (D6) the follow items were recorded: the subjective comparative perception, informed by the patient, of the quality of vision between the eyes, the objective monocular VA and the appearance of the central corneal epithelial suture line. Results: With regard to subjective quality of vision perception, it was observed that $48.8 \%$ of patients did not realize the difference between the eyes, while $51.2 \%$ did $(41.9 \%$ reported better quality of vision in the eye with the oval shape and $9.3 \%$ reported better vision in the eye with the circular shape). With regard to the VA (Snellen), the average in the oval shape of 0.62 was significantly higher $(p<0.001)$ than the circular shape of 0.53. As for the appearance of the epithelial suture line, in $64.3 \%$ of the cases there was a lower density of the suture line in the eyes submitted to the oval shape, $31.0 \%$ did not demonstrate difference and in $4.8 \%$ of eyes submitted to oval shape the suture line was denser. These results are due to the fact that in the oval shape the epithelial cells come from non-equidistant edges of the corneal periphery to the center and run across a smaller area, determining a smoother, sometimes off-center, epithelial suture line. Conclusion: The change in the shape of the corneal epithelial removal in photorefractive keratectomy (PRK), from circular to oval shape, determines a better recovery of the postoperative visual acuity (VA).
\end{abstract}

Keywords: Photorefractive keratectomy; Visual acuity; Cornea; Epithelium; Excimer laser

\section{ReSUMO}

Objetivo: Verificar se a modificação no formato da desepitelização corneana na ceratectomia fotorrefrativa (PRK), de circular para oval, modifica a recuperação da acuidade visual (AV) no pós-operatório. Métodos: Foram avaliados prospectivamente 43 pacientes submetidos ao PRK bilateral e simultâneo. De forma randomizada em cada paciente, um olho foi desepitelizado no formato circular e o outro no formato oval. No sexto dia de pós-operatório (D6) foram registradas a percepção subjetiva pelo paciente da qualidade de visão comparativa entre os olhos, a AV objetiva monocular e o aspecto do empilhamento epitelial corneano. Resultados: Em relação à percepção subjetiva da qualidade de visão, observou-se que 48,8\% dos pacientes não perceberam diferença entre os olhos e 51,2\% perceberam diferença (41,9\% referiram melhor qualidade de visão no olho da desepitelização oval e 9,3\% referiram melhor visão no olho da desepitelização circular). Em relação à AV (Snellen), a média na desepitelização oval, de 0,62, foi significativamente superior (p<0,001) que na circular, de 0,53. Quanto ao empilhamento epitelial, em 64,3\% houve menor densidade do empilhamento nos olhos submetidos à desepitelização oval, em $31,0 \%$ não foi identificada diferença e em 4,8\% dos olhos submetidos à desepitelização oval o empilhamento foi maior. Tais resultados se devem ao fato de que na desepitelização oval as células epiteliais provêm de bordas não equidistantes do centro da córnea e percorrem uma área menor, determinando um empilhamento epitelial central mais suave. Conclusão: Verificou-se que a modificação no formato da desepitelização corneana no PRK para oval, determinou uma significativa melhora da recuperação da AV.

Descritores: Ceratectomia fotorrefrativa; Acuidade visual; Córnea; Epitélio; Excimer laser

\footnotetext{
${ }^{1}$ Refractive Surgery Department, Eye Institute, Ophthalmology School, Faculdade de Medicina do ABC, Santo André, SP, Brazil;

${ }^{2}$ Medicine student, Faculdade de Medicina do ABC, Santo André, SP, Brazil;

${ }^{3}$ Ophthalmology School, Faculdade de Medicina do ABC, Santo André, SP, Brazil.

Study carried out at Faculdade de Medicina do ABC and Centro Oftalmológico Laser Ocular ABC.

The authors declare no conflicts of interests.

Received for publication 15/02/2016 - Accepted for publication 24/06/2016.
}

Rev Bras Oftalmol. 2016; 75 (4): 269-73 


\section{INTRODUCTION}

$\mathbf{T}$ The photorefractive keratectomy (PRK) and laser in situ keratomileusis (LASIK) are the main kinds of refractive surgery performed today ${ }^{(1)}$.

Regardless of the type of surgery, long-term visual results are equivalent, and both techniques present its peculiarities and its complications ${ }^{(2)}$.

The main advantages of LASIK over PRK are the lower incidence of postoperative pain and the fast recovery of the visual acuity due to the preservation of corneal epithelium ${ }^{(3-4)}$.

The postoperative pain of PRK is currently controlled by various procedures that complement each other: oral analgesia ${ }^{(5)}$, topic non-steroidal anti-inflammatory agents ${ }^{(6)}$, indication of therapeutic contact lenses with high oxygen permeability ${ }^{(7)}$, use of balanced frozen saline ${ }^{(8)}$, droplets of postoperative dilute anesthetic and use of intraoperative mitomycin $\mathrm{C}^{(9)}$.

It's still a challenge to shorten the time of postoperative low VA of the PRK ${ }^{(10)}$.

Low AV observed in early postoperative PRK is due to the formation of disordered stacking lines of epithelial cells from the periphery of the cornea that are directed to the center, being located on the visual axis ${ }^{(11)}$. As the marking of the corneal area to be de-epithelialized in PRK is routinely made by a circular optical zone marker centered on the pupil, the process of reepithelialization starts at the edge of the de-epithelialized area which, being circular, is equidistant from the center of the pupil and therefore, the cells from this edge must achieve the center of the cornea at the same time, accentuating the aforementioned stacking phenomenon ${ }^{(12)}$.

In the literature studied we found only one report submitted by Dr. Marguerite McDonald suggesting that the change in the form of corneal epithelium removal in PRK would have beneficial influence on postoperative visual acuity. In order to reduce the low VA that occurs between the third and fourth PRK postoperative day, she suggests that the corneal epithelium might be removed in oval format instead of the circular one, and thus the epithelial closing line would be found outside the center and the epithelial stacking would not be directly over the visual axis ${ }^{(13)}$.

There is no other work describing and evaluating this benefit in a controlled way.

The present study aims to determine in a prospective and randomized way if the change in the format of the corneal epithelium removal in PRK from circular to oval provides better recovery of the postoperative visual acuity.

\section{MethodS}

A prospective, interventional, masked study was performed to the randomized patient at the Refractive Surgery Department of the Eye Institute in the Ophthalmology School at Faculdade de Medicina do ABC and at Centro Oftalmológico Laser Ocular $\mathrm{ABC}$. The oval epithelium removal in one eye was compared to the circular one in the contralateral eye in 43 patients undergoing simultaneous bilateral photorefractive keratectomy (PRK) operated between May and June 2015 with Excimer Laser WaveLight EX500 da Alcon. This sample size was given by the demand of the period in the ambulatory.

The study was approved by the Research Ethics Committee of Faculdade de Medicina do ABC and by the Ethics Committee Plataforma Brasil under the number 42989814.2.0000.0082. This study was also registered in the Registro Brasileiro de Ensaios Clínicos under number RBR-2w7phk. All patients included agreed with the completion of the study after detailed explanation and signature of informed consent.

Inclusion criteria were: patients with formal indication for bilateral PRK with preoperative visual acuity corrected equal to 1.0 in both eyes and difference between the spherical equivalent of ametropy of each eye less than 1 diopter. The epithelium removal was made in each patient included in this study at the beginning of the PRK procedure, with oval format in one eye and circular format in the contralateral, randomly determined before the procedure.

The inclusion criteria were: any intraoperative complication and patients who for some reason discontinued the use of therapeutic contact lenses or presented any ophthalmologic complication prior to the evaluation of the 6th postoperative day.

The oval marker was developed specifically for the present study with the following characteristics (Figure 1): larger diameter with $9.5 \mathrm{~mm}$, smallest diameter with $7.5 \mathrm{~mm}$, and height of $5 \mathrm{~mm}$ with a handling handle on the side, delimiting an internal area of $55.93 \mathrm{~mm}^{2}$ [radius $1(4.75) \mathrm{x}$ radius $2(3.75) \mathrm{x}$ radius $\pi$ (3.14)]. The circular marker used was the conventional one for marking an optical zone of $9.5 \mathrm{~mm}$ diameter, $6.5 \mathrm{~mm}$ height and a handle on the side, delimiting an internal area of $70.86 \mathrm{~mm}^{2}$ [radius (4.75) x $\pi(3.14)$ ].

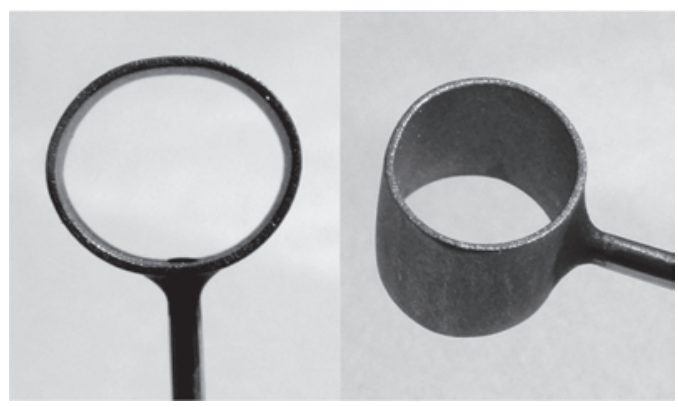

Figure 1: Oval optical zone marker (diameter 1: $9.5 \mathrm{~mm} /$ diameter 2: $7.5 \mathrm{~mm}$ / height: $5.0 \mathrm{~mm}$ )

The surgical technique used followed the following times: topical anesthesia and antisepsis of the skin; use of sterile adhesive fields for isolation of eyelashes and blepharostat with aspiration; application of frozen balanced saline solution on the cornea for 10 seconds, pre-prepared with rod-shaped cellulose sponge and kept in freezer until its application; marking the area to have the epithelium removed with oval marker in one eye and circular in the contralateral, or vice versa, according to random determination; mechanical removal of the corneal epithelium with a blunt edge spatula, within the limits and the format of each marker; photoablation by excimer laser; mitomycin C (MMC) $0.02 \%$ placed inside an optical zone marker of high profile, $6.5 \mathrm{~mm}$ in diameter, positioned in the center of the area treated for similar times in each eye of the patient, from 20 to 45 seconds, according to the amount of ablation for treatment of ametropy; aspiration of MMC; abundant irrigation of the ocular surface with balanced saline solution; application on the cornea of balanced saline frozen by 10 seconds; placement of silicone hydrogel therapeutic contact lens and instillation of a droplet of antibiotic eyedrops moxifloxacin $0.5 \%$ and a droplet of the corticosteroid eyedrops prednisolone acetate $1 \%$. 
When the eye receiving the oval marking presented astigmatism, the largest diameter of the marker was placed in the same direction of the axis of the greater astigmatism ablation. This way, the larger treatment area was within the area of epithelium removal of larger extension, bounded by the oval marker.To facilitate such positioning an protractor axis was placed near the cornea according to the axis of refractive astigmatism.

Postoperative patients unaware of which eye had the epithelium ovally and circularly removed were instructed to apply the same eyedrops in both eyes, starting the procedure 2 hours after surgery, as follows: topic non-steroid anti-inflammatory eyedrops nepafenac $0.1 \%, 1$ drop every 8 hours for 3 days; antibiotic eyedrops moxifloxacin $0.5 \%, 1$ drop every 8 hours for 7 days; corticosteroid eyedrops fluormetolone acetate $0.1 \%, 1$ drop every 6 hours for 3 weeks, and artificial tears sodium carmelose $0.5 \%, 1$ drop every 4 hours for 2 months. Oral paracetamol $500 \mathrm{mg}$ was prescribed as pain reliever in association with phosphate codeine $30 \mathrm{mg}$, every 12 hours for 3 days.

The first postoperative assessment was performed the day after the procedure. The symptoms, bio-microscopic aspect of the previous segment and positioning of the therapeutic contact lenses in both eyes were assessed.

Patients were instructed to return for further assessment in the 6th postoperative day. On that day, three items were assessed: the subjective perception, informed by the patient, of the quality of vision by comparison between the eyes; the visual acuity of each eye measured with the Snellen scale in decimals and the bio-microscopic assessment of the cornea performed by the medical examiner, comparing in a subjective way the epithelial stacking.

In some patients, in which the difference in the aspect of reepithelialization between the eyes was clearly perceptible in slit-lamp examination, a photographic documentation showing the corneal stacking in right eye (RE) and in the left eye (LE) (figures 2, 3 and 4) was made.

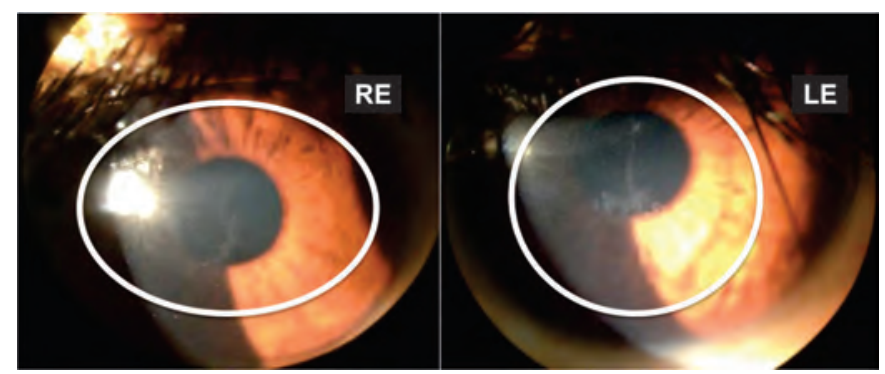

Figure 2: Aspect of the epithelial stacking in the 6th postoperative day of PRK. RE with oval and LE with circular epithelium removal.

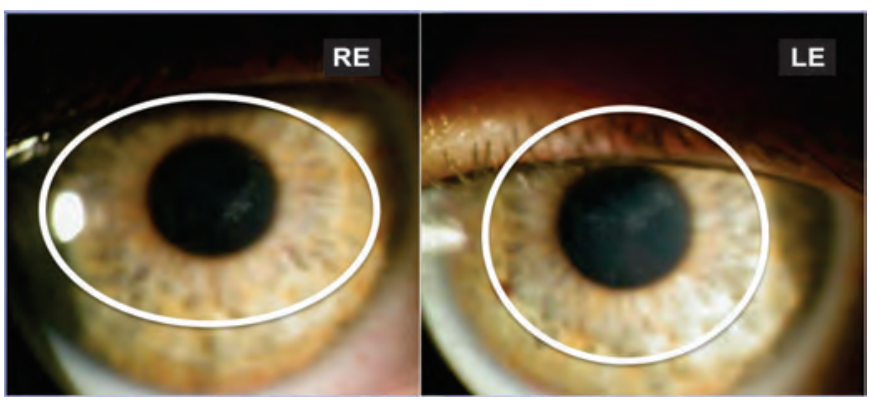

Figure 3: Aspect of the epithelial stacking in the 6th postoperative day of PRK. RE with oval and LE with circular epithelium removal.

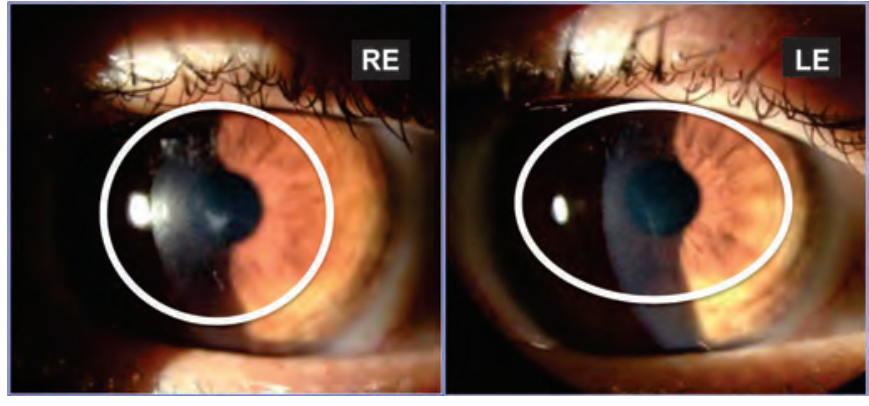

Figure 4: Aspect of the epithelial stacking in the 6th postoperative day of PRK. RE with oval and LE with circular epithelium removal.

After the complete corneal reepithelialization was found of both eyes in the 6th postoperative day (D6), the therapeutic contact lenses were removed. The patients learned about the medicines, development of visual acuity, with return to the doctor's scheduled for a month.

Initially all variables were analyzed descriptively. For quantitative variables, this analysis was made by observation of the minimum and maximum values, and the averages, standard deviations and median were calculated. For the qualitative variables the absolute and relative frequencies were calculated.

The non-parametric Wilcoxon test was used to compare the two techniques, because the assumption of normality of the data was rejected.

The significance level used for the quantitative tests was $5 \%$.

\section{ReSULTS}

Of the 43 patients in this analysis, 17 were man $(39.5 \%)$ and 26 women $(60.5 \%)$. The age ranged between 22 and 45 years, and the average age was 30.79 years. The visual acuity in postoperative decimal ranged from 0.30 to 0.80 in patients subjected to circular epithelium removal technique, and from 0.30 to 1.00 in those subjected to oval technique.

Statistically significant difference was noted between the two techniques in relation to the recovery of visual acuity at D6 (Table 1). The oval epithelium removal technique presented better recovery when compared to the circular technique (Graph 1).

\section{Graph 1}

\section{Box-plot of VA in D6 according to the technique used.}

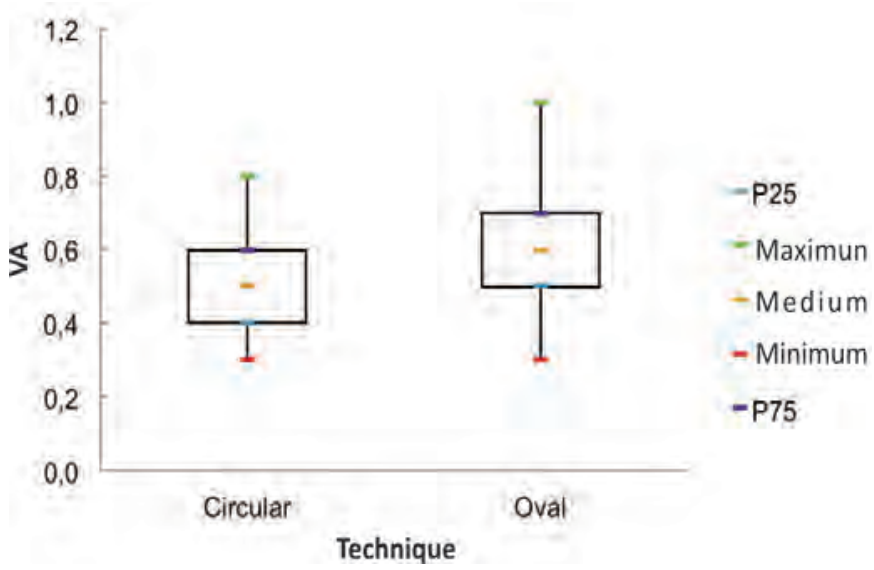


Table 1

VA values described in each epithelium removal technique applied in D6.

\begin{tabular}{llcccccccc}
\hline Technique & $\mathbf{n}$ & Average & SD & Minimum & Maximum & P25 & Median & P75 & P-value* \\
\hline Circular & 43 & 0,53 & 0,14 & 0,30 & 0,80 & 0,40 & 0,50 & 0,60 & $<0,001$ \\
Oval & 43 & 0,62 & 0,14 & 0,30 & 1,00 & 0,50 & 0,60 & 0,70 & \\
\hline
\end{tabular}

(*) descriptive level of probability of non-parametric Wilcoxon test; SD: standard deviation

In relation to the subjective perception of quality of vision in 43 patients, it was observed that $48.8 \%$ of patients did not notice the difference between the eyes, and $51.2 \%$ noticed a difference (41.9\% noticed better quality of vision in the eye of oval deepithelization and $9.3 \%$ noticed better quality of vision in the eye of circular deepithelization) (Graph 2).

\section{Graph 2}

Frequency distribution of the $\mathbf{4 3}$ patients in relation to the perception of better VA in D6.
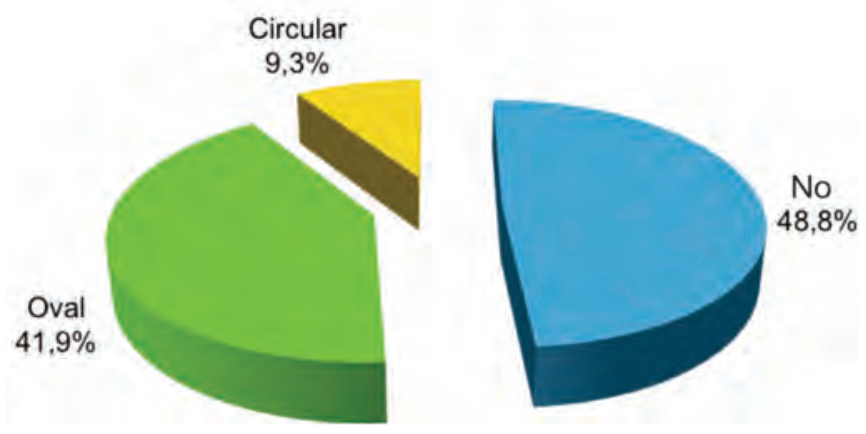

Regarding the subjective biomicroscopic evaluation of density of epithelial stacking made by the examiner, $64.3 \%$ of patients had less stacking in the eyes submitted to oval deepithelization, in $31.0 \%$ no difference was identified, and in $4.7 \%$ of patients there was more stacking in the eyes with oval deepithelization (Graph 3).

\section{Graph 3}

Frequency distribution of the 43 patients in relation to the epithelial stacking density in D6

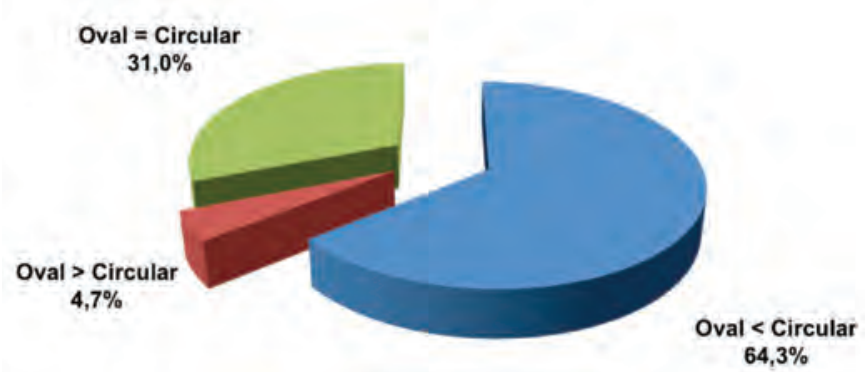

The primary endpoint of improvement in the visual acuity was confirmed in decimal with the Snellen chart in the sixth postoperative day, which ranged from 0.30 to 0.80 in patients subjected to circular deepithelization technique, and from 0.30 to 1.00 in those subjected to oval technique

\section{Discussion}

Several theories explain the corneal scarring, and when it occurs after deepithelization, the same pattern of corneal physiological turnover is followed, involving the processes of cellular migration and multiplication. At the beginning, the cells that surround the denuded area flatten, glide and migrate to cover the defect. After that, the mitotic activity occurs in the basal cells, restoring the multilayer structure of the epithelium ${ }^{(14)}$.

It has been shown that there is a rate of mitosis in the corneal epithelium that is higher in the periphery of the cornea, near the limbo, in relation to the center. This allows a flow of epithelial cells from a site with a higher rate of mitosis to the region of lower rate of mitosis, which would be the corneal center ${ }^{(15)}$.

The concept of physiological corneal "turnover" may be explained by the theory $\mathrm{X}, \mathrm{Y}, \mathrm{Z}$ that has been proven by many studies and experiments, where $\mathrm{X}$ is the proliferation of epithelial basal cells, $\mathrm{Y}$ is the proliferation and centripetal migration of limbal cells, and $Z$ would be superficial epithelial loss. Therefore, $\mathrm{X}+\mathrm{Y}=\mathrm{Z}$, so that there is a constant steady state ${ }^{(16)}$. It is estimated that this process occurs every 7 to 10 days ${ }^{(17)}$. The present study showed that said centripetal migration is completed in D6, but no emphasis was given to the microscopic appearance of this phenomenon.

There is a difference in the electric potential of $6 \mathrm{mV}$ between the cornea and the posterior pole of the eye. Thus, the human eye behaves like a dipole, oriented on the anteroposterior axis, the cornea being the positive pole. Once the cells suffer influence of the electromagnetic field for having iron ions and ionic currents inside, they tend to be organized in concentric circles ${ }^{(18)}$.

A similar aspect was presented in the theory known as "Hurricane and Blizzard Keratopathy", which describes that the corneal reepithelization occurs through the distribution of epithelial cells of spiral mode and clockwise influenced by the electromagnetic field of the eye during the process of basal epithelium "turnover"(11).

The corneal reepithelization in a large circular lesion occurs in a non-uniform way. There is a progressive decrease in the deepithelized area with the formation of epithelial leaflets from different areas of the edge of the circumference of the lesion advancing to the center and forming the convex front lines. These convex lines are in the center of the lesion, forming a single line of contact in shape of the letter Y, which soon disappears ${ }^{(14)}$. The exam carried out on slit lamp in D6 also showed the presence of this scar in $\mathrm{Y}$ in most patients.

In this study, the occurrence of these events may have been changed by modifying the format of the deepithelization area, as suggested in one report found in the literature concerning the modification of the format of the corneal deepithelization in PRK and its influence on $\mathrm{VA}^{(13)}$. When you change the format of the deepithelization from circular to oval, there was a better 
visual acuity at D6, both in the subjective evaluation perceived by the patient (41.9\% in the oval against $9.3 \%$ in the circular) and the objective measure with the Snellen chart (average of 0.62 in the oval and 0.53 in the circular, $\mathrm{p}<0.001)$. Possibly, this process for better recovery of VA is due to the different distances that the migration of epithelial cells travels, and due to not reaching the center at the same time, forming a fainter line contact at the center of the cornea, and it may even be offset from the visual axis. The healing rate of the epithelial defect has been related to the area of injury. Large lesions heal faster than smaller lesions ${ }^{(19)}$. Based on this theory, the circular technique deepithelization a larger area $\left(70.86 \mathrm{~mm}^{2}\right)$, and presents a more exuberantly closing, determining an increased epithelial hyperplasia in the visual axis with greater involvement of VA quality. In the oval technique, the epithelial defect area is smaller $\left(55.93 \mathrm{~mm}^{2}\right)$, leading to a slower and probably smoother healing, with less involvement of VA.

The significant results observed in this study are unprecedented because there are no studies in the literature assessing if deepithelization formats different from circular in the surgical procedure of PRK change the time of recovery of the postoperative visual acuity.

\section{ConcLusion}

This study showed that changing the format of the corneal deepithelization in photorefractive keratectomy (PRK) from circular to oval provides better recovery of visual acuity using simple, easy-to-use instruments with a significant impact in the result of this refractive procedure in the first postoperative days.

\section{ReFERENCES}

1. Netto MV, Espíndola RF, Nogueira RGF, Campos M, Ambrósio Jr R, Andrade NL. Censo Brasileiro de Cirurgia Refrativa. Arq Bras Oftalmol. 2013;76(1):29-32.

2. Francesconi CM, Leoratti MC. Excimer laser. In: Tratado brasileiro de catarata e cirurgia refrativa. Rio de Janeiro: Cultura Médica; 2014.

3. Shortt AJ, Allan BD, Evans JR. Laser-assisted in-situ keratomileusis (LASIK) versus photorefractive keratectomy (PRK) for myopia. Cochrane Database Syst Rev [Internet] 2013. Disponível em: http://www.ncbi.nim.nih.gov/pubmed/23440799.

4. Walker MB, Wilson SE. Recovery of uncorrected visual acuity after laser in situ keratomileusis or photorefractive keratectomy for low myopia. Cornea. 2001; 20(2):153-5.

5. Faktorovich E. New Approaches to Pain Management after PRK: Both oral and topical options show early promise. Ophthalmol Manag [Internet] 2009. [cited 2016 June 21]. Available from: h t t p :// www.oph thal mologymanagement.com/ articleviewer.aspx?articleID=103393.
6. Altersitz K. NSAID regimen important in perioperative care of laser surface ablation patients: Experts in the field shared their drug choices and dosing regimens for pain control. Ocular Surgery News U.S. Edition [Internet] 2007.[cited 2016 June 21]. Available from: http://www.healio.com/ophthalmology/corneaexternal-disease/news/print/ocular-surgery-news/\{8ef80ee1-7c39$48 \mathrm{dc}-9 \mathrm{~d} 1 \mathrm{f}-\mathrm{dc} 6873 \mathrm{~d} 407 \mathrm{df}\} / \mathrm{nsaid}$-regimen-important-inperioperative-care-of-laser-surface-ablation-patients.

7. Taylor RK, Caldwell CM, Payne AM, Apsey DA, Townley RJ, Reilly CD, Panday VA. Comparison of 3 silicone hydrogel bandage soft contact lenses for pain control after photorefractive keratectomy. J Cataract Refract Surg. 2014;40(11):1798-804.

8. Ribeiro LG. Estudo da eficácia do uso intraoperatório de solução salina balanceada congelada como coadjuvante na analgesia pós ceratectomia fotorrefrativa [tese]. Santo André: Faculdade de Medicina do ABC; 2012.

9. Fortes AC, Martinelli EJ, Ribeiro LG, Corpa JH, Tarcha FA, Rehder JR. Ação do anestésico tópico diluído e da mitomicina sobre a sintomatologia e reepitelização corneana no pós-operatório da ceratectomia fotorrefrativa. Rev Bras Oftalmol. 2013;72(4):237-43.

10. Boughton B. PRK: Feeling better and healing faster. EyeNet Magazine. September; 2008.[cited 2016 June 21]. Available from. www.aao.org.

11. Dua HS, Gomes JA, Singh A. Corneal epithelial wound healing. Br J Ophthalmol. 1994;78(5):401-8.

12. American Academy of Ophthalmology. Refractive Surgery BCSC Basic and Clinical Science Course, American Academy of Ophthalmology. Section 13, 2014-2015.

13. Lake N. Surface ablation: closing the pain gap with LASIK. Newsletter Refractive Outlook [a Internet]. 2013. [cited 2016 June 21]. Available from: http://isrs.aao.org/resources/june-2013.

14. Dua HS, Forrester JV. Clinical patterns of corneal epithelial wound healing. Am J Ophthalmol. 1987;104(5):481-89.

15. Bron AJ. Vortex patterns of the corneal epithelium. Trans Ophthalmol Soc UK. 1973;93:455-72.

16. Thoft RA, Friend J. The X, Y, Z hypothesis of corneal epithelial maintenance. Invest Ophthalmol Vis Sci. 1983;24(10):1442-3.

17. Hanna C, O'Brien JE. Cell production and migration in the epithelial layer of the cornea. Arch Ophthalmol. 1960;64:536-9.

18. Berson EL. Electrical phenomena in the retina. Adler's physiology of the eye and clinical applications. 7th ed. London: CV Mosby; 1981.

19. Matsuda M, Ubels JL, Edelhauser HF. A larger corneal epithelial wound closes at a faster rate. Invest Ophthalmol Vis Sci. 1985;26 (6):897-900.

\section{Corresponding author:}

Edmundo José Velasco Martinelli.

LASER OCULAR ABC.

Av. Portugal, 830, Jardim Bela Vista, Santo André, São Paulo. ZIP Code: 09040-001

Email: edmundo@pobox.com 